\title{
TANTANGAN YANG DIHADAPI KAWACHI DAIKICHI DALAM PERANNYA SEBAGAI SEORANG IKUMEN PADA FILM USAGI DROP LIVE ACTION
}

\author{
P.P.Suradika ${ }^{1}$ N.N.Suartini ${ }^{2}$ I.W.Sadyana ${ }^{3}$ \\ ${ }^{123}$ Jurusan Pendidikan Bahasa Jepang, Universitas Pendidikan Ganesha, Singaraja,Bali \\ e-mail: suradikapebri@gmail.com \\ nnsuartini@undiksha.ac.id wayan.sadyana@undiksha.ac.id
}

\begin{abstract}
Abstrak
Tujuan dari penelitian ini adalah untuk mendeskripsikan tantangan yang dihadapi Kawachi Daikichi dalam perannya sebagai seorang ikumen. Subjek yang digunakan dalam penelitian ini adalah film Usagi Drop Live Action yang dirilis pada tahun 2010. Penelitian ini merupakan penelitian deskriptif kualitatif yang mana peneliti adalah instrumen utama dan dibantu oleh kartu data. Dalam penelitian ini digunakan konsep tantangan, gender, ikumen serta bentuk-bentuk peran ayah dalam pengasuhan anak dan pekerjaan rumah tangga untuk menganalisis tantangan yang dihadapi Daikichi dalam perannya sebagai seorang ikumen. Hasil dari penelitian ditemukan 12 data mengenai tantangan yang dihadapi Daikichi dalam perannya sebagai seorang ikumen. Tantangan dari lingkungan masyarakat berjumlah 2 data, tantangan dari lingkungan keluarga berjumlah 2 data, tantangan dari tempat kerja berjumlah 4 data, tantangan dari diri sendiri berjumlah 3 data dan tantangan dari regulasi aturan pemerintah di Jepang berjumlah 1 data. Berdasarkan hasil penelitian ini, dapat diketahui bahwa fenomena ikumen yang sedang terjadi di Jepang tidak seindah yang dibayangkan oleh masyarakat karena dalam kenyataannya masih terdapat banyak tantangan yang harus dihadapi oleh seorang ikumen. Meskipun pemerintah telah melakukan bermacam-macam kebijakan untuk menunjang perkembangan fenomena ikumen. Tetapi dalam penerapannya di masyarakat, kebijakan-kebijakan tersebut tidak berjalan sesuai dengan yang diharapkan. Dengan adanya penelitian mengenai tantangan yang dihadapi seorang ikumen dalam film Usagi Drop Live Action diharapkan dapat bermanfaat bagi pembaca, pebelajar bahasa Jepang dan dapat dijadikan sumber referensi penelitian sejenis yang meneliti fenomena ikumen di Jepang dari segi yang berbeda serta lebih rinci dan mengkhusus.
\end{abstract}

Kata-kata kunci : ikumen, pengasuhan, gender, film Usagi Drop Live Action

\section{要旨}

本論の目的はイクメンの役割を果たすための河内大吉河地大吉の拒否を明らかす ること。対象は2010年に発行したウサギドロップの映画である。研究者がデータカ 一ドを作成し、それをもとにした定性的記述による研究である。分析としては訂正 分析を基にしてジェンダー論、イクメンの概念、家庭における男性の託児法を使用 すること。結果はウサギドロップにおいて12点のイクメンの拒否があり、社会的に おける拒否は2点、自らの家庭のは2点、職場におけるのは4点、じぶんの展望なのは 3点、政府政策のは1点で明らかになった。本結果はイクメンの存在に対して日本社 会には大きい拒否があるのが見られる。日本政府はイクメンの社会化政策をしたけ れども、人々の拒否で、その政策を受け入れないとウサギドロップの中から明らか になった。

キーワード :イクメン、託児、ジェンダー、ウサギドロップ 


\section{Pendahuluan}

Kondisi sosial masyarakat Jepang terus mengalami perubahan dari tahun ketahun. Salah satunya adalah adanya perubahan dalam hal mengatur rumah tangga, terutama mengenai peran dan identitas ayah dalam masyarakat Jepang modern. Contoh paling popular adalah munculnya fenomena ikumen sebagai salah satu gaya hidup masyarakat Jepang modern. Ikumen merupakan gabungan dari kata iku yang berasal dari ikuji (mengasuh anak) dan men yang berarti laki-laki. Sebuah istilah yang menggambarkan seorang laki-laki yang aktif terlibat dalam pengasuhan anak

Kondisi perekonomian Jepang menjadi salah satu hal yang memengaruhi perubahan keterlibatan ayah dalam pengasuhan anak. Merosotnya kondisi ekonomi Jepang membuat perspektif pengasuhan anak oleh ayah mulai berubah. Kondisi sosial tempat pekerja perempuan semakin banyak karena masalah ekonomi membuat pemerintah merasa perlu melibatkan ayah dalam hal pengasuhan anak. Salah satu kebijakan yang dikeluarkan oleh pemerintah adalah work-life balance, yaitu sebuah kebijakan yang bertujuan membantu masyarakat dalam membangun masa depan yang ramah keluarga tetapi tetap bisa berkarya di perusahaan tempat mereka bekerja

Selain itu, fenomena menurunnya angka kelahiran di Jepang atau yang dikenal dengan fenomena "shoushika", juga merupakan sebuah kondisi sosial yang menggerakan pemerintah untuk memberikan perspektif terhadap peran gender antara laki-laki dan perempuan yang berbeda dengan sebelumnya. Oleh karena itu, pemerintah Jepang mengeluarkan beberapa kebijakan "family-friendly", yang memberikan kemudahan bagi pekerja dalam menjalani pekerjaan dan berkeluarga.

Perkembangan fenomena ikumen dimanfaatkan berbagai pihak untuk membuat produk yang berhubungan dengan ikumen. Contohnya, sebuah film bertemakan ikumen yang berjudul "Usagi Drops Live Action" dirilis pada tahun 2010. Selain film, ada juga komik, buku, majalah, bahkan produk mandi untuk ayah seperti produk "nikkei kids". Dengan dukungan dari pemerintah, peran laki-laki di dalam keluarga mengalami perubahan secara bertahap. Kini laki-laki Jepang dianggap memiliki peranan penting di dalam hal pengasuhan anak, meskipun memiliki tingkatan yang berbeda dengan perempuan. Tetapi, Meskipun pemerintah telah mencanangkan berbagai program untuk menunjang perkembangan fenomena ikumen pada masyarakat Jepang, pada kenyataannya, program-program tersebut masih belum bisa dijalankan sesuai harapan karena sebagian besar masyarakat Jepang masih memandang rendah laki-laki yang mengurus anak dan mereka lebih memprioritaskan laki-laki yang bekerja untuk mencari nafkah dibandingkan dengan mengasuh anak.

Fenomena ikumen ini merupakan topik yang sangat menarik untuk diteliti, hal ini dibuktikan dengan adanya beberapa penelitian terdahulu yang membahas masalah mengenai fenomena ikumen di Jepang. Salah satunya adalah penelitian yang dilakukan oleh Atsuko Oyama (2014) yang membahas tentang peran ayah di awal abad ke-21 yang aktif terlibat mengasuh anak dan disebut sebagai ikumen. Para ayah tersebut merupakan kebalikan dari para ayah di abad ke-20 yang lebih fokus mencari nafkah untuk keluarga Penelitian ini menggunakan film Usagi Drop Live Action yang dirilis pada tahun 2010 yang juga merupakan tahun terpopulernya ikumen di Jepang. Sehingga cerita yang terdapat dalam film ini merupakan kejadian yang dialami oleh para ikumen dalam masyarakat Jepang. Ikumen yang banyak diketahui masyarakat luas adalah kegiatan pengasuhan anak yang dilakukan oleh ayah kepada anak kandungnya. Namun, dalam film ini, peran ikumen justru dilakukan oleh laki-laki yang masih lajang kepada anak dari kakeknya. Adegan-adegan dalam film ini akan menunjukkan tantangan yang dihadapi Daikichi saat menjalani peran sebagai seorang ikumen.

Penelitian ini merupakan penelitian deskriptif kualitatif yang tujuannya untuk menjawab rumusan masalah yaitu bagaimanakah tantangan yang dihadapi Kawachi Daikichi dalam perannya sebagai seorang ikumen yang digambarkan pada film Usagi Drop Live Action

\section{KAJIAN PUSTAKA}

Jurnal Pendidikan Bahasa Jepang | 279 


\section{Gender}

Gender berarti perbedaan perilaku yang bukan biologis dan bukan kodrat Tuhan. Adanya perbedaan gender antara kaum laki-laki dan perempuan pada proses berikutnya melahirkan peran gender. Peran-peran ini dapat dipertukarkan dan bergantung pada masa, keadaan dan budaya masing. Konsep gender merupakan sebuah konsep yang sangat luas karena konsep ini dapat muncul dalam berbagai bidang ilmu pengetahuan seperti biologi, sosial, bahasa dan politik. Gender sendiri berasal dari bahasa latin "genus" yang bermakna "jenis atau tipe". Dalam bahasa Inggris sendiri, gender bermakna jenis kelamin. Akan tetapi, istilah Gender yang sebenarnya lebih mengacu sebagai suatu konstruksi sosial-budaya yang membedakan laki-laki dan perempuan, sedangkan seks lebih mengacu pada perbedaan laki-laki dan perempuan dari sudut biologis (BKKBN, 2007).

\section{Teori Nurture}

Menurut teori nurture, adanya perbedaan perempuan dan laki-laki pada hakikatnya adalah hasil konstruksi sosial-budaya sehingga menghasilkan peran dan tugas yang berbeda. Perbedaan tersebut menyebabkan perempuan selalu tertinggal dan terabaikan peran dan konstribusinya dalam hidup berkeluarga, bermasyarakat, berbangsa dan bernegara (BKKBN, 2007).

Perjuangan untuk persamaan laki-laki dan perempuan sulit dicapai karena berbagai hambatan, baik dari nilai agama maupun budaya. Karena itu, aliran nurture melahirkan paham sosial konflik yang memperjuangkan kesamaan proporsional dalam segala aktivitas masyarakat, seperti di tingkatan manajer, menteri, militer, DPR, partai politik dan bidang lainnya (BKKBN, 2007). Untuk mencapai tujuan tersebut, dibuatlah program khusus (affirmative action) guna memberikan peluang bagi pemberdayaan perempuan yang kadang kala berakibat timbulnya reaksi negatif dari kaum laki-laki karena adanya sikap apriori terhadap perjuangan tersebut (BKKBN, 2007).

\section{Ikumen}

Moteki (2011) menjelaskan bahwa Ikumen adalah laki-laki yang mengasuh anak dan menikmati kegiatan pengasuhan anak tersebut, atau laki-laki yang secara sukarela mengasuh anak tanpa adanya unsur paksaan. Melalui pengasuhan anak, para laki-laki di Jepang juga akan dapat mendewasakan dirinya sendiri. Selain itu, Moteki (2011) mengungkapkan bahwa laki-laki yang secara sukarela mengasuh anak walaupun sambil bekerja dapat disebut dengan Ikumen.

Ikumen Project (2010) menjelaskan bahwa laki-laki yang mengasuh anak dan menikmatinya merupakan seorang ikumen. Laki-laki yang baru berencana atau memiliki impian untuk melakukan kegiatan mengasuh anak dimasa depan juga dapat disebut sebagai seorang ikumen, meskipun laki-laki tersebut belum berkeluarga dan masih lajang. Dengan hadirnya fenomena Ikumen di Jepang tentu akan membuat perubahan terhadap cara hidup istri, anak dan struktur keluarganya. Selain itu, para laki-laki di Jepang diharapkan mampu lebih aktif berpartisipasi dalam hal pengasuhan anak. Sehingga kondisi sosial masyarakat di Jepang akan semakin membaik dengan adanya partisipasi tersebut.

Menurut Executive Committee Kobe Ikumen dijelaskan bahwa ikumen merupakan urusan semua laki-laki yang terlibat langsung dengan pengasuhan anak. Pernyataan tersebut menunjukkan bahwa peran sebagai seorang ikumen tidak mesti dilakukan oleh seorang ayah terhadap anak kandungnya, bisa dilakukan oleh kakek kepada cucunya atau seorang laki-laki terhadap keponakannya yang yatim piatu. Kegiatan pengasuhan anak merupakan salah satu bentuk gagasan yang harus dikembangkan dan dilakukan di lingkungan masyarakat sekitar agar semua laki-laki bisa melibatkan dirinya dalam kegiatan pengasuhan tersebut.

Oyama (2014) berpendapat bahwa seorang Ikumen tidak hanya terlibat dalam pengasuhan anak seperti menenangkan kondisi anak, menghadiri kegiatan yang 
diselenggarakan di sekolah anak, memuji dan memarahi anak serta bermain bersama anak, tetapi dapat pula terlibat dalam pekerjaan-pekerjaan rumah tangga seperti berbelanja ke Mal untuk kebutuhan anak, membersihkan rumah, merawat anak yang sakit dan mengepang rambut.

\section{Metode}

\section{Metode dan Teknik Pengumpulan Data}

Dalam pengumpulan data, digunakan metode kepustakaan, yaitu data diperoleh melalui film Usagi Drop Live Action dan sumber-sumber lain yang dapat mendukung serta memudahkan proses penelitian dalam pengumpulan data. Sumber-sumber yang dimaksud berupa buku-buku dan laporan penelitian yang terkait dengan objek penelitian yaitu mengenai peran seorang laki-laki sebagai seorang ikumen dalam masyarakat Jepang. Teknik pengumpulan data yang digunakan dalam penelitian ini adalah teknik studi dokumen. Menurut Sugiyono (2009) teknik studi dokumen adalah teknik pengumpulan data yang tidak langsung ditunjukkan kepada subjek penelitian. Dokumen yang diteliti dalam penelitian ini adalah film Jepang yang berjudul Usagi Drop Live Action.

\section{Metode dan Teknik Analisis Data}

Dalam analisis data kualitatif, Bogdan (dalam Sugiyono, 2009) menyatakan bahwa analisis data adalah proses mencari dan menyusun secara sistematis data yang diperoleh dari hasil menyimak, catatan lapangan dan bahan-bahan lain, sehingga dapat mudah dipahami dan temuannya dapat diinformasikan kepada orang lain teknik analisis data yang digunakan dalam penelitian ini adalah Analysis Interactive Model dari Miles dan Huberman (2007), yang membagi langkah-langkah dalam kegiatan analisis data dengan beberapa bagian yaitu pengumpulan data (data collection), reduksi data (data reduction), penyajian data (data display) dan simpulan (conclusion).

\section{Hasil Dan Pembahasan}

Jumlah data yang dikumpulkan dari film Usagi Drop Live Action untuk penelitian mengenai tantangan yang dihadapi Daikichi sebagai seorang ikumen adalah sebanyak 12 data. Tantangan dari lingkungan masyarakat berjumlah 2 data, tantangan dari lingkungan keluarga berjumlah 2 data, tantangan dari tempat kerja berjumlah 4 data, tantangan dari diri sendiri berjumlah 3 data dan tantangan dari regulasi aturan pemerintah Jepang berjumlah 1 data.

\section{Tantangan dari lingkungan masyarakat. \\ Data ke-1}

Situasi film: Pada adegan ini, terlihat Daikichi dan Rin sedang berada di sebuah Mal untuk membeli pakaian. Daikichi memilihkan beberapa pakaian untuk Rin seperti baju, rok dan celana. Namun Rin hanya memilih celana panjang karena ia lebih menyukainya. Saat Daikichi sedang memilih baju untuk Rin, sesekali pengunjung di Mal tersebut memerhatikan kegiatan yang Daikichi lakukan. Daikichi yang melakukan kegiatan tersebut untuk pertama kalinya terlihat malu ketika diperhatikan oleh orang-orang disekitarnya

\section{Tantangan sebagai seorang ikumen:}

Sebagian besar laki-laki di Jepang berasumsi bahwa kegiatan berbelanja ke Mal adalah tugas perempuan dan laki-laki yang melakukan kegiatan tersebut akan terlihat unmasculine oleh masyarakat di sekitarnya. Sehingga, menemani Rin berbelanja di Mal menjadi tantangan yang sangat berat untuk dijalani oleh Daikichi sebagai seorang ikumen karena pandangan masyarakat di sekitar dan Daikichi juga tidak tahu sepatu yang cocok untuk digunakan anak kecil perempuan.

\section{Tantangan dari lingkungan keluarga \\ Data ke-2}

Situasi film: Saat Daikichi memutuskan untuk merawat dan mengasuh Rin, ibu Daikichi sangat melarang hal tersebut karena sebagai orang tua dari Daikichi tentunya ia paham tentang bagaimana sulitnya mengasuh anak kecil, apalagi Daikichi tidak mempunyai 
pengalaman sama sekali tentang pengasuhan anak. Ibu Daikichi juga takut jika saat Daikichi mengasuh Rin akan sangat mengganggu karirnya yang bekerja sebagai pegawai kantoran. Daikichi tidak menghiraukan saat dinasehati oleh ibunya dan ia menjawab bahwa Rin yang sebenarnya menanggung beban yang sangat berat karena setelah ayah Rin meninggal tidak ada lagi yang mau megasuhnya. Mendengar jawaban Daikichi, ibunya hanya diam dengan wajah yang nampak kesal lalu memberikan perlengkapan yang dibutuhkan oleh Rin kepada Daikichi.

\section{Tantangan sebagai seorang ikumen:}

Meskipun kampanye ikumen telah digembar-gemborkan pemerintah Jepang melalui berbagai media seperti dibuatnya dorama, diluncurkannya berbagai jenis buku, komik dan lain-lain, tetapi hal ini masih belum dapat diterima oleh masyarakat Jepang secara keseluruhan. Ada beberapa kelompok masyarakat yang masih menganut perspektif tradisional dalam keluarga yaitu adanya pembagian pekerjaan yang jelas antara laki-laki dan perempuan. Keluarga di Jepang yang masih menganut perspektif tradisional ini tentu menjadi tantangan tersendiri untuk laki-laki yang berperan dalam pengasuhan anak sebagai seorang ikumen.

\section{Tantangan dari tempat kerja \\ Data ke-3}

Situasi film: Seperti kebanyakan pegawai kantoran di Jepang, Daikichi hampir menghabiskan sebagian besar waktunya di tempatnya bekerja, sehingga dia sangat kelelahan karena juga harus terlibat untuk mengasuh dan merawat Rin. Oleh karena itu, Daikichi kemudian membuat keputusan untuk menurunkan jabatannya di kantor tempatnya bekerja agar dia memiliki waktu lebih banyak untuk mengurus Rin. Keputusan tersebut dipilihnya karena sebagai pengasuh Rin, ia harus menyiapkan perlengkapannya, kemudian mengantarnya ke tempat penitipan anak, apalagi jarak antara rumah, tempat penitipan anak dan kantornya cukup jauh untuk ditempuh. Meskipun pimpinan dan rekan-rekannya dikantor berharap agar Daikichi mengurungkan niatnya, namun Daikichi tetap kepada keputusannya tersebut. Setelah jabatannya diturunkan, otomatis ia akan memiliki waktu lebih banyak bersama Rin.

\section{Tantangan sebagai seorang ikumen:}

Jam kerja perusahaan di Jepang tidak menoleransi pekerjanya yang mengasuh anak, sehingga keterlibatan laki-laki dalam mengasuh dan terlibat dalam pekerjaan rumah tangga menjadi sangat sedikit. Misalnya kegiatan bermain di luar ruangan dan kegiatan membersihkan rumah yang sangat jarang dilakukan oleh laki-laki di Jepang. Hal ini disebabkan karena hampir semua pekerja kantoran di Jepang sangat tunduk kepada perusahaan tempatnya bekerja. Semua aturan yang dibuat oleh perusahaan harus dipatuhi sepenuhnya oleh seorang pegawai kantoran. Dan sangat jarang seorang pegawai kantoran yang terlibat dalam pekerjaan rumah tangga. Hal tersebut tentunya menjadi tantangan yang sangat sulit bagi laki-laki di Jepang untuk terlibat dalam pengasuhan anak dan pekerjaan rumah tangga.

\section{Tantangan dari diri sendiri \\ Data ke-4}

Situasi film: Setelah mendapatkan tempat penitipan anak yang sesuai untuk Rin, Daikichi mulai menyiapkan perlengkapan yang dibutuhkan oleh Rin. Pada adegan ini, Daikichi mengajak Rin untuk pergi ke sebuah Mal, di tempat tersebut Daikichi membelikan Rin segala perlengkapan seperti baju, sepatu, handuk, tas dan lain-lain. Rin memilih barang-barang yang ingin dibelinya dan Daikichi dengan senang hati memenuhinya, berbeda dengan sebelumnya saat pergi berbelanja ke Mal, kali ini Daikichi terlihat lebih menikmati saat berbelanja ke Mal dengan Rin. Meskipun Daikichi terlihat menikmati kegiatannya berbelanja, namun ia masih kurang mengerti untuk memilihkan baju, sepatu dan perlengkapan lainnya yang cocok dan sesuai untuk anak perempuan.

Tantangan sebagai seorang ikumen: Sebagai seorang laki-laki yang tidak mempunyai pengalaman mengasuh anak perempuan, membuat Daikichi tidak memiliki bayangan 
tentang pakaian anak perempuan Muhayaroh (2015) dalam penelitiannya menjelaskan bahwa laki-laki yang mengasuh anak masih dianggap aneh di Jepang, maka pada saat bertemu dengan ibu-ibu yang ada di tempat perbelanjaan, seorang akan sangat bingung ketika harus berkali-kali menjawab pertanyaan, "Kenapa ayahnya yang merawat anak, ibunya pergi kemana?". Berdasarkan survei yang dilakukan oleh BICSP, persentase keterlibatan laki-laki dalam berbelanja untuk keperluan sehari-hari hanya $14 \%$ pada tahun 2005 bahkan berkurang menjadi 12,4\% pada tahun 2009. Fakta ini menunjukkan bahwa laki-laki di Jepang sangat jauh dari kegiatan rumah tangga salah satunya adalah berbelanja ke Mal untuk keperluan anak.

\section{Tantangan dari regulasi aturan pemerintah di Jepang \\ Data ke-5}

Situasi film: Setelah bertemu dengan ibu kandung dari Rin, terlintas dibenak Daikichi untuk mengganti nama marga dari Rin dengan nama marga yang dimiliki Daikichi, saat Daikichi mengantar Rin ke tempat penitipan anak, Daikichi bertanya kepada Rin untuk mengubah namanya menjadi Kawachi Rin dari nama sebelumnya yaitu Kaga Rin. Hal ini dikarenakan Daikichi berpikir bahwa untuk memudahkan administrasi Rin saat akan memasuki jenjang sekolah, ia harus memastikan data diri dari Rin agar lebih jelas setelah tinggal dengannya, salah satunya adalah nama keluarga yang digunakan oleh Rin. Namun Rin tidak menyetujui hal tersebut dan lebih suka menggunakan nama sebelumnya yaitu Kaga Rin. Saat itu, Daikichi juga tidak memaksakan permintaannya kepada Rin dan segera mengizinkannya masuk ke tempat penitipan anak.

\section{Tantangan sebagai seorang ikumen:}

Selain keterlibatannya dalam memonitor kegiatan anaknya di sekolah, seorang ayah juga harus memastikan agar data diri anaknya sesuai dengan registrasi yang dibuat oleh pemerintah Jepang salah satunya adalah nama keluarganya. Dalam sistem registrasi keluarga di Jepang mengharuskan setiap orang Jepang yang telah menikah menggunakan nama keluarga yang sama (Sugimoto, 1997). Misalnya ibu Toyota menikah dengan bapak Suzuki, setelah resmi menikah mereka harus menggunakan satu nama keluarga saja yaitu Toyota atau Suzuki saja.

Seiring dengan evaluasi yang terus dilakukan pemerintahan Jepang tentang penggunaan nama keluarga. Pemerintah dewan administrasi Jepang kemudian melakukan revisi terhadap peraturan tersebut. Bahwa pasangan bisa memilih nama keluarga yang sama atau nama keluarga yang berbeda saat mereka telah menikah. Selain itu mereka juga harus memutuskan apakah anak mereka akan menggunakan nama keluarga ayah atau nama keluarga ibunya (Sugimoto, 1997). Saat Daikichi menawarkan nama keluarganya untuk digunakan oleh Rin. Daikichi mendapat tantangan karena Rin menolak hal tersebut tanpa alasan yang jelas dan lebih menyukai nama keluarga yang telah digunakannya yaitu Rin Kaga. Meski sedikit bingung, Daikichi tidak terlalu memaksa Rin untuk menggunakan nama keluarganya

\section{Simpulan dan Saran}

Berdasarkan hasil penelitian yang telah dilakukan mengenai tantangan yang dihadapi Daikichi sebagai seorang ikumen dalam film Usagi Drop Live Action, maka dapat disimpulkan bahwa fenomena ikumen yang ada di masyarakat Jepang masih menghadapi banyak tantangan dan belum bisa berkembang dengan baik. Misalnya pelecehan terhadap laki-laki yang mengasuh anak, pandangan masyarakat bahwa tugas mengasuh anak dan pekerjaan rumah tangga adalah tugas seorang perempuan, kesulitan mendapatkan cuti dari perusahaan untuk merawat anak dan kesulitan memperoleh promosi kerja di perusahaan saat mengasuh anak.

Meskipun pemerintah telah melakukan bermacam-macam kebijakan untuk menunjang perkembangan fenomena ikumen. Tetapi dalam penerapannya di masyarakat, 
kebijakan-kebijakan tersebut tidak berjalan sesuai rencana, misalnya masih banyak laki-laki di Jepang yang masih berpandangan tradisional bahwa mengasuh dan merawat anak adalah tugas perempuan, pengetahuan laki-laki di Jepang yang kurang terhadap pengasuhan anak, sistem kerja di Jepang yang lebih memprioritaskan laki-laki untuk bekerja dan masih banyak perusahaan yang tidak mendukung berjalannya program cuti untuk lakilaki yang mengasuh anak.

Dengan

adanya penelitian mengenai fenomena ikumen dalam film Usagi Drop Live Action diharapkan dapat bermanfaat bagi pembaca, pembelajar Bahasa Jepang dan dapat dijadikan sumber referensi penelitian sejenis. Mengingat penelitian ini masih sederhana dan terdapat banyak kekurangan maka perlu dikembangkan penelitian sejenis yang meneliti fenomena ikumen dari segi yang berbeda dan lebih mengkhusus.

\section{Daftar Pustaka}

Benesee Institute for Child Sciences and Parenting. 2011. Wishing to be Ikumen: The Ideal and Reality of Young Japanese Fathers (Online), diakses 05 Mei 2015 dari http://www.childresearch.net/data/ec/2011 01.html

BKKBN. 2007. Konsep Teori dan Gender. Modul Program Pembelajaran Jarak Jauh Pengarusutamaan Gender (PJJ-PUG).

Executive Committee Kobe Ikumen. 2010. Koube Ikumen to ha. Koube Ikumen (Online), diakses 29 Juni 2016 dari http://www.kobeikumen.com

Ghiamitasya, M. 2012. Pola pengasuhan Anak di Jepang. Perubahan Peran Ayah Dalam Pengasuhan Anak di Jepang Pada Era Shoushika (Online), diakses 20 Juni 2016 dari http://journal.unair.ac.id

Ikumen Project. 2010. Ikumen Purojekuto ha. Ikumen Purojekuto (Online), diakses 29 April 2016 dari http://ikumen-project.jp

Miles, Mattew B dan A. Michael Huberman. 2007. Analisis Data Kualitatif, buku sumber tentang metode-metode baru. Jakarta: Universitas Indonesia Press

Moteki, K. 2011.「Ikumen」 wo Shirou.「Ikumen」Buumu ha tourai suru no ka ? (Online), diakses 28 Mei 2016 dari https://www.j-smeca.jp.

Muhayaroh, I. 2015. Fenomena Ikumen Sebagai Salah Satu Perubahan Peran dan Identitas Ayah dalam Masyarakat Jepang Modern. Disertasi tidak diterbitkan. Depok : Program Studi Kajian Wilayah Jepang, Program Pascasarjana, Universitas Indonesia.

Oyama, Atsuko. 2014. Old and New Types of Masculinities, and Ikumen. Gender, Family, and New Styles of Fatherhood: Modernization and Globalization in Japan (Online), diakses 04 Mei 2016 dari https:/ /arizona.openrepository.com 
Sugimoto, Y. (1997). An introduction to Japanese society. United Kingdom: Cambridge University Press.

Sugiyono, 2009. Metode Penelitian Pendidikan. Bandung: ALFABETA. 